\title{
Serum Chemistry of UDA Rams Fed Graded Levels of Parkia biglobosa (African Locust Bean) Fruit Pulp
}

\author{
Aljameel KM*, Muhammad N and Abdulkarim A \\ Department of Animal Science, Usmanu Danfodiyo University, Nigeria
}

Submission: May 08, 2017; Published: July 26, 2017

*Corresponding author: Aljameel KM, Department of Animal Science, Usmanu Danfodiyo University, Sokoto, Nigeria, Email: Muhdkjameel@gmail. com

\begin{abstract}
An experiment was conducted to evaluate the effect of varying levels of Parkia biglobosa fruit pulp on the performance of UDA rams. The animals were fed diets containing 0,10,20 and 30\% inclusion levels of $P$. biglobosa fruit pulp in a completely randomized experimental design replicated four times. Blood sample evaluation was carried out at the end of the experiment. Serum evaluation indicated significant differences in direct bilirubin, chlorine, bicarbonate, potassium, albumin, HDL, LDL, triglycerides, cholesterol, creatinine, urea and glucose (P<0.05) Further studies should be carried out with other breeds of sheep to evaluate the effect of the test ingredient on lactation and other physiological functions of the animals.
\end{abstract}

Keywords: UDA rams; Serum enzymes and electrolytes; African locust bean

\section{Introduction}

Tropical tree leaf species in north central Nigeria can provide palatable and nutrition fodder during long period of scarcity by harvesting heir leaves. It is indicated that there are many advantages of the forages from multipurpose tree crops [1]. Others added that leaf fodder of some trees is almost as nutrition as that of the leguminous fodder crops [2]. However, the presence of anti nutritional factor (ANF) such as tannin when present above the safety limit will be injurious to ruminant. In north central Nigeria where there is intense animal husbandry, the demand for forage is ever growing.

Many factors are known to affect the chemical composition of feedstuffs such as stage of growth, species or variety [3], drying method, growth environment [4] and soil types [5]. Onwuka \& Akinsoyinmu [6] stated that the presence of mineral elements in animal feed is vital for the animals' metabolic process. This goes to buttress the idea that common salt $(\mathrm{NaCl})$ supplementation is ideal in goat and sheep where browse is the sole feed [7]. The use of herbaceous forage legumes in livestock production systems for ruminants in the tropics has increased as the legumes are rich in protein which is usually the most limiting nutrient in tropical animal diets [8]. However, this tree legume specie has some anti-nutritional factors which might have a negative effect on the blood metabolites of animals consuming them [9].
Blood chemistry evaluation is simply identifying the numerous chemical substances found in the blood. The analysis of these substances will provide clues to the functioning of the major body systems. Blood chemistry tests are performed on the serum derived from whole blood. Serum is the liquid remaining after whole blood has clotted in the sample tube.

\section{Materials and Methods}

\section{Experimental site}

The study was conducted at the Usmanu Danfodiyo University Livestock Teaching and Research Farm. The farm is located within the main campus of the University at about $10 \mathrm{~km}$ North of Sokoto Metropolis in Wamako Local Government Area of Sokoto State. Sokoto is located in the SUDAno-Sahelian zone in extreme North-Western part of Nigeria. It lies between longitude $4^{\circ} 8^{\prime} \mathrm{E}$ and $6^{\circ} 54^{\prime} \mathrm{E}$ and latitudes $12^{\circ} 0^{\prime} \mathrm{N}$ and $13^{\circ} 58^{\prime} \mathrm{N}$ and at altitude of $350 \mathrm{~m}$ above sea level [10]. The average annual environmental temperature is $28.3^{\circ} \mathrm{C}\left(82.9^{\circ} \mathrm{F}\right)$.

However, the maximum daytime temperatures are most of the year generally under $40^{\circ} \mathrm{C}\left(104.0^{\circ} \mathrm{F}\right)$. The low humidity of Sokoto state makes the heat bearable. Heat is more severe in the state in March and April. But the weather in the state is always cold in the mornings and hot in the afternoons except during 
the hamattan period [11]. The warmest months are February to April; where daytime temperature exceeds $42^{\circ} \mathrm{C}\left(107.6^{\circ} \mathrm{F}\right)$ [11]. The rainy season is from late May to October. Rainfall starts late and ends early with annual rainfall ranging between $500 \mathrm{~mm}$ to $700 \mathrm{~mm}$. There are two major seasons in the state namely: wet and dry seasons. The dry season starts from October and last up to April, in some part and may extend to May or June in other part. The wet season on the other hand begins in most part of the state in May and last up to September or October [11]. The hamattan, a dry, cold and fairly dusty wind is experienced in state between November and February of each year due to high environmental temperature.

\section{Sources and processing of experimental feeds}

The locust bean powder used in this experiment was purchased from Achida market, Sokoto state. While the remaining feed materials that includes maize, rice offal, cowpea husk, cowpea haulms, cotton seed cake and salt were purchased from Sokoto Kara market. Maize and cowpea hay are crushed to reduce their particle size, cotton seed cake, cowpea husk, rice milling waste, premix, bone meal and salt are obtained directly from Sokoto central market.

\section{Experimental Design and Diet Formulation}

Table 1: Gross composition of the experimental diets.

\begin{tabular}{|c|c|c|c|c|}
\hline Ingredients & Diet 1 & Diet 2 & Diet 3 & Diet 4 \\
\hline Locust bean & 0 & 10 & 20 & 30 \\
\hline Maize & 17 & 10 & 4.25 & 0.8 \\
\hline $\begin{array}{c}\text { Cowpea } \\
\text { husk }\end{array}$ & 7.6 & 9.6 & 9.7 & 9.9 \\
\hline $\begin{array}{c}\text { Cowpea } \\
\text { haulms }\end{array}$ & 17.2 & 17.7 & 17.7 & 7.5 \\
\hline Rice offal & 12.45 & 5.45 & 0.15 & 3.3 \\
\hline $\begin{array}{c}\text { Cotton seed } \\
\text { cake }\end{array}$ & 42.25 & 43.75 & 44.7 & 45 \\
\hline Salt & 0.5 & 0.5 & 0.5 & 0.5 \\
\hline Premix & 0.5 & 0.5 & 0.5 & 0.5 \\
\hline Bone meal & 2.5 & 2.5 & 2.5 & 2.5 \\
\hline Total & 100 & 100 & 100 & 100 \\
\hline
\end{tabular}

A completely randomized experimental design (CRD) was used in this experiment with number of animals representing replication and graded levels of $P$. biglobosa fruit pulp representing treatments. Four animals were allocated to each treatment each animal serving as replicate. The weight of the animals was balanced between treatments. Each animal was housed in a pen measuring $2 \mathrm{~m} \square 1 \mathrm{~m}$, which was previously disinfected. Each group was assigned to one of the experimental diets and fed ad libitum in the morning for 12 weeks. Water was offered ad libitum. Four complete experimental diets were formulated with graded levels of locus bean fruit pulp at 0, 10,20, and $30 \%$ inclusion levels. The four experimental diets are used to feed the animals. The diets were designated as treatments
1, 2, 3 and 4 in the experiments. The gross compositions of the experimental diet are shown in Table 1 . The diets were is nitrogenous and is caloric.

\section{Experimental animals and their management}

The sixteen yearlings UDA rams used in this experiment were purchased from Achida market, Sokoto state. The apparently healthy sheep were stationed at the Livestock Teaching and Research Farm Usmanu Danfodiyo University Sokoto, for 7 days for adaptation to new environment. The animals were dewormed using Albendazole based on the manufacturer's recommendation the animals received oxytetracycline injection for possible bacterial infection. The feeding pens were cleaned regularly and disinfected a week before the commencement of the experiment. Faces and urine of the animals were removed every day from the feeding pens to ensure adequate hygiene and minimal ammonia accumulation. Feed and water troughs were cleaned every morning before feeding.

\section{Blood sample collection}

Blood samples were collected once from all the animals at the end of the experiment. The blood samples were aseptically collected via jugular vein using separate sterilized disposable $5 \mathrm{ml}$ syringe and 23 gauge needle. The samples from each replicate were collected in plain tubes, and tubes coated with floride oxide. The samples in floride oxide bottles was used for glucose level analysis, while the samples in the plain tubes is centrifuged for five minutes to separate the serum from the blood at room temperature. The serum was taken to chemical pathology lab of Usmanu Danfodiyo Teaching Hospital for analysis.

\section{Proximate analysis of the experimental diets}

Standard analytical methods [12] was used to determined dry matter (DM), crude protein (CP), ether extract (EE), crude fibre (CF) and nitrogen free extract (NFE). The gross energy of the samples was determined by bomb calorimetry [12]. The fibre fraction of the feed was analysed according to the method of Van Soest et al. [13].

\section{Statistical Analysis}

All the data collected are subjected to Analysis of variance using completely randomized design [14]. Least significant difference (LSD) was used to separate the means. Correlation analysis procedure was used to assess the relationship between the measured variables. Statview statistical package [15] was used in data analysis.

\section{Results and Discussion}

\section{Serum chemistry of UDA rams fed graded levels of $P$. biglobosa fruit pulp}

Results (Table 2) indicated a significantly higher Albumin $(\mathrm{g} / \mathrm{dl})$, LDL $(\mathrm{Mmol} / \mathrm{l})$, Urea $(\mathrm{Mmol} / \mathrm{l})$ and glucose $(\mathrm{Mmol} / \mathrm{l})$ for animals placed in treatments 3 and $4(\mathrm{P}<0.05)$. However 
treatments 2 and 4 are the same $(\mathrm{P}>0.05)$ in terms of albumin (Mmol/l), HDL (Mmol/l), LDL (Mmol/l), creatinine (Mmol/l) and cholesterol $(\mathrm{Mmol} / \mathrm{l})$. Treatments 1 and 4 are the same $(\mathrm{P}>0.05)$ in terms of LDL (Mmol/l), triglycerides ( $\mathrm{Mmol} / \mathrm{l})$ and creatinine $(\mathrm{Mmol} / \mathrm{l})$. There were no significant difference for globulin and total protein across the treatments $(\mathrm{P}>0.05)$.

Table 2: Serum chemistry of Uda fed graded levels of $P$. biglobosa fruit pulp.

\begin{tabular}{|c|c|c|c|c|c|}
\hline \multicolumn{6}{|c|}{ Treatments } \\
\hline Parameter & 1 & 2 & 3 & 4 & SEM \\
\hline Albumin (g/dl) & $2.45^{\mathrm{c}}$ & $2.65^{b}$ & $2.83^{\mathrm{a}}$ & $2.70^{\mathrm{ab}}$ & 0.04 \\
\hline Globulin (g/dl) & 3.9 & 3.75 & 3.63 & 3.45 & 0.37 \\
\hline Total protein $(\mathrm{g} / \mathrm{dl})$ & 6.35 & 6.4 & 6.45 & 6.15 & 0.35 \\
\hline HDL (mmol/L) & $54.00^{\mathrm{b}}$ & $76.00^{\mathrm{b}}$ & $143.5^{\mathrm{a}}$ & $56.0^{\mathrm{b}}$ & 7.34 \\
\hline LDL (Mmol/L) & $28.5^{\mathrm{ab}}$ & $11.25^{\mathrm{b}}$ & $63.25^{\mathrm{a}}$ & $40.00^{\mathrm{ab}}$ & 10.76 \\
\hline $\begin{array}{l}\text { Triglycerides } \\
\text { (Mmol/L) }\end{array}$ & $37.5^{\mathrm{ab}}$ & $34.5^{\mathrm{b}}$ & $31.0^{\mathrm{b}}$ & $45.0^{\mathrm{a}}$ & 2.36 \\
\hline Creatinine (Mmol/L) & $90.0^{\mathrm{a}}$ & $76.50^{\mathrm{b}}$ & $76.50^{\mathrm{b}}$ & $83.50^{\mathrm{ab}}$ & 3.21 \\
\hline Cholesterol (Mmol/L) & $0.50^{\mathrm{a}}$ & $0.65^{\mathrm{b}}$ & $0.60^{\mathrm{ab}}$ & $0.70^{\mathrm{b}}$ & 0.41 \\
\hline Urea (Mmol/L) & $4.80^{\mathrm{b}}$ & $5.0^{\mathrm{b}}$ & $6.50^{\mathrm{a}}$ & $6.95^{\mathrm{a}}$ & 0.23 \\
\hline Glucose (Mmol/L) & $3.50^{c}$ & $3.95^{\mathrm{b}}$ & $4.45^{\mathrm{a}}$ & $4.33^{\mathrm{a}}$ & 0.11 \\
\hline
\end{tabular}

a, b, c means in the same row with different superscripts are significantly different $(P<0.05)$

HDL: High Density Lipoprotein; LDL: Low Density Lipoprotein

Serum electrolytes and enzymes profile of UDA rams fed graded levels of $P$. biglobosa

Result (Table 3) showed that treatments 1, 2 and 3 had a significantly higher $(\mathrm{P}<0.05)$ for direct bilirubin $(\mathrm{Mmol} / \mathrm{l})$, chlorine (Mmol/l), bicarbonate (Mmol/l) and sodium (Mmol/l).
There were no significance difference $(\mathrm{P}>0.05)$ between treatments 2 and 3 in potassium $(\mathrm{Mmol} / \mathrm{l})$ and between treatments 1 and 2 in terms of ALT ( $\mathrm{u} / \mathrm{l})$ chlorine and bicarbonate levels $(\mathrm{P}>0.05)$. Result indicated no significant differences in total bilirubin across the treatments (Table 3 ).

Table 3: Serum electrolytes, and Enzymes of Uda fed graded levels of $P$. biglobosa fruit pulp.

\begin{tabular}{|c|c|c|c|c|c|}
\hline \multicolumn{6}{|c|}{ Treatments } \\
\hline Parameters & 1 & 2 & 3 & 4 & SEM \\
\hline $\operatorname{AST}(\mathrm{u} / \mathrm{L})$ & 76 & 59.5 & 83 & 101 & 16.66 \\
\hline $\operatorname{ALT}(\mathrm{u} / \mathrm{L})$ & $9.0^{\mathrm{b}}$ & $9.5^{\mathrm{ab}}$ & $13.5^{\mathrm{ab}}$ & $14.0 \mathrm{a}$ & 1.05 \\
\hline $\operatorname{ALP}(\mathrm{u} / \mathrm{L})$ & 429.5 & 496 & 385 & 448 & 38.75 \\
\hline $\begin{array}{l}\text { Direct bilirubin } \\
(\mathrm{Mmol} / \mathrm{L})\end{array}$ & $0.08^{\mathrm{ab}}$ & $0.11^{\mathrm{a}}$ & $0.10^{\mathrm{a}}$ & $0.03^{\mathrm{b}}$ & 0.02 \\
\hline $\begin{array}{l}\text { Total bilirubin } \\
(\mathrm{Mmol} / \mathrm{L})\end{array}$ & 0.45 & 0.46 & 0.43 & 0.41 & 0.07 \\
\hline Chlorine (Mmol/L) & $99.50^{\mathrm{a}}$ & $98.50^{\mathrm{a}}$ & $98.25^{\mathrm{a}}$ & $92.00^{\mathrm{b}}$ & 0.9 \\
\hline $\begin{array}{l}\text { Bicarbonate } \\
\text { (Mmol/L) }\end{array}$ & $24.5^{\mathrm{a}}$ & $24.5^{\mathrm{a}}$ & $25.3^{\mathrm{a}}$ & $22.0^{\mathrm{b}}$ & 0.37 \\
\hline Potassium (Mmol/L) & $4.13^{\mathrm{b}}$ & $4.23^{\mathrm{ab}}$ & $4.35^{\mathrm{a}}$ & $4.25^{\mathrm{ab}}$ & 0.04 \\
\hline Sodium (Mmol/L) & $142.5^{\mathrm{a}}$ & $141.5^{\mathrm{a}}$ & $138.5^{\mathrm{b}}$ & $132.0^{c}$ & 0.78 \\
\hline
\end{tabular}

$a, b, c$ means in the same row with different superscripts are significantly different $(P<0.05)$

ALP: Alkaline Phosphate; ALT: Alanine Aminotransferase; AST: Aspartate Aminotransferase

\section{Discussion}

\section{Serum chemistry of UDA rams fed graded level $P$. biglobosa fruit pulp}

The HDL and LDL obtained in the present study are higher than the those obtained by Garba (2014) but were within the range reported by Antunovic et al. [16]. The urea, Albumin,
Globulin, total protein and creatinine were within the normal reference values as reported by Duncan et al. (1994) and Khan $\&$ Scott (2012). The cholesterol falls below the normal reference range though the values significantly $(\mathrm{P}<0.05)$ increase with increasing level of the test ingredient, low cholesterol is recognized in inherent deficiencies, intestinal mal-absorption/ 
mal-digestion of lipo-protein [16], the test ingredient is reported to have low protein and high energy [17]. The glucose concentration obtained recorded was above the normal reference value as reported by Duncan et al. (1994) and Khan and Scott (2012). This mild elevation could be attributed to high sugar intake brought about by addition of P. biglobosa fruit pulp. The decrease in cholesterol is a factor contributing to synthesis of glucose or could reduce glucose uptake by the body cells.

The urea levels of the serum being within the normal reference range infers that the work rate of the liver and kidney is normal and the likelihood of the anti-nutritive or the feed being toxic can be discarded thus the test material could be termed safe for in sheep diet. Also total protein being within the normal reference range is an indication that protein synthesis is adequate [18]. The creatinine values were within the normal reference range although not on the higher side. This could be attributed to the fact that the experimental animals are in growing stage because creatinine concentration tend to increase progressively with age [19].

\section{Serum electrolytes and enzymes}

The bicarbonate, potassium, total and direct bilirubin, and AST are within the normal values while the chlorine and sodium are slightly below the normal range. The sodium and potassium were similar to the findings of Aruwayo et al. [20] and are similar to the values obtained by Garba [18] when certain browse plants including Parkia leaves where fed to post-partum yankasa ewes. The electrolyte levels evaluated being within the normal range is an indication that the test ingredient may not interfere with the normal renal function of the animals. High ALP could indicate liver flukes and pyrrolizidine alkaloid toxicity. However, high levels of ALP can be normal in growing animals due growth of bones [21]. The ALP values being high are an indicative of high quality protein in the diet. The bilirubin and AST are within the normal values. This indicates that the animals may not have any liver disorder and the test ingredient as well did not interfere with liver dysfunction. Even though the ALT is slightly below the reference range, it increases significantly $(\mathrm{P}<0.05)$ with increase P. biglobosa fruit pulp from diet 1 to 4 [22-26].

\section{Conclusion}

From the study it can be concluded that the test ingredient P. biglobosa fruit pulp may not have any could be termed safe to be used for feeding sheep as it will not interfere with their renal or liver function.

\section{References}

1. Devendra C (1997) Crop residues for feeding animals in Asia: Technology development and adoption in crop/livestock system. In: C. Renard (Ed.), Crop residues in sustainable mixed/livestock farming system Oxen, CAB international, pp. 241-267.

2. Reddy DV, Elanchezian N (2008) Evaluation of tropical tree leaves as ruminant feedstuff based on cell contents, cell wall fractions and polyphenolic compounds.
3. Agbala-Dohnani A, Noziere P, Clement G, Dorea, M (2001) Insacco degradability, chemical and morphological composition of 15 varieties of European rice straw. Animal Feed Science and Technology 94: 15-27.

4. Mupangwa JF, Ngongoni NT, Topps JH, Ndlovu P (1997) Chemical composition and dry matter of forage legumes Casia rotundiforliacv. Wynn, Lablab purpereuscv. Highworth and Macroptiliumaltro purpereuscv. Siratro at 8 weeks of growth (parenthesis). Animal Feed Science and Technology 69(1-3): 167-178.

5. Thu NV, Preston TR (1999) Rumen enviroment and feed degradability in swamp buffaloes fed different suplements. Livestock Research for Rural Development 11:1-7.

6. Onwuka CFI, Akinsoyinmu AO (1988) Mineral constituents of some browse plant used in ruminat feeding in Sourthern Nigeria. Nigerian Journal of Animal Production 15: 57-62.

7. Oni AO, Onwuka CFI, Arigbede OM, Anele UY, Yusuf K, et al. (2010) Chemical composition and in Sacco degradability of four varieties of cassava leaves grown in south western Nigeria in the rumen of sheep. Tropical Animal Health and Production 42(7): 1385-1393.

8. Ajayi FT, Babayemi OJ (2008) Comparative in vitro evaluation of mixtures of panicum maximum cv Ntchissi stylo (Stylosanthes guanensis), Lablab (Lablab purpureus), Centro (Centrosema pubescens) and histrix (Aeschynomene histrix). Livestock Research for Rural Development 20(6): 1-15.

9. Fetuga BL, Babatunde GM, Oyenuga VA (1974) Protein quality of some unusual protein foods-African locust bean seed. British Journal of Nutrition 32(1): 117-122.

10. Mamman AB, Oyebanji JO, Petters WS (2000) Nigeria: A people united, a future assure (survey states) (2nd edn), Gabumo Publishing Company Limited., Calabar, Nigeria.

11. SSMIYS (2010) Sokoto State Government Dairy. Ministry of Information and Youth, Sport and Culture.

12. AOAC (1990) Official Methods of Analysis ( $15^{\text {th }}$ edn), Association of Official Analytical Chemists. Washington DC, USA.

13. Van Soest PJ, Robertson JB, Lewis BA (1991) Methods for dietary fibre, neutral detergent fibre and non-starch polysaccharides in relation to animal nutrition. Journal of Dairy Science 74(10): 3583-3597.

14. Steel RGD, Torrie JA (1980) Principles and Procedure of Statistics. McGraw-Hill Book Company Inc., New York, USA.

15. SAS (2002) Statview statistical package. SAS incorporated, Newyork.

16. Antunovic Z, Spernda M, Sencic D, Novosele J, Steiner Z et al. (2012) Influence of age on some blood parameters of lambs in organic production. Macedonian Journal of Animal Science 1(2): 11-15.

17. Gernah DI, Atolagbe MO, Echegwo CC (2007) Nutritional composition of the African locust bean (Parkia biglobosa) fruit pulp. Nigerian Food Journal 25(1): 190-196.

18. Garba Y (2014) post-partum performance of small ruminants fed native browses in semi-arid. Bayero University Kano, Nigeria.

19. Myer DJ, Enrich DJ (1992) Veterinary laboratory medicine interpretation and diagnosis. Philadelpia: WB Saunders co., USA.

20. Aruwayo A, Maigandi SA, Mallami BS, Daneji AI (2011) Hematological and biochemical parameters of UDA lambs fed graded levels of alkalitreated neem kernel cake. Nigerian Journal of Basic and Applied Science 19(2): 277-278.

21. Infovets (2015) ALP reference values. Retrieved from infovets.com/ books/smrm/D/D080.htm

22. Baker FJ, Silverston RE (1985) Introduction to medical laboratory Technology (6 $6^{\text {th }}$ edn), Butterwort, London, p.746. 
23. Bush BM (1991) Interpretation of laboratory results from small animal clinician. Black Well Scientific Publication, United Kindom, p. 515.

24. Promkot C, Wanapat M (2004) Ruminal degradation and intestinal digestion of crude protein of tropical resource using nylon bags and three-step in vitro procedure in dairy cattle. In Proceedings of the Agricultural Seminar, Animal science/ Animal husbandry, Held at Sofitel Raja Orchad Hotel.
25. Thu NV, Preston TR (1999) Rumen enviroment and feed degradability in swamp buffaloes fed different suplements. Livestock Research for Rural Development 11: 1-7.

26. Von Keyserlin K, Swift M L, Puchala R, Shelford V (1996) Degradability characteristics of dry matter and crude protein of forages in ruminants. Animal Feed Science and Technology 57(4): 291-311.

\section{Your next submission with Juniper Publishers} will reach you the below assets

- Quality Editorial service

- Swift Peer Review

- Reprints availability

- E-prints Service

- Manuscript Podcast for convenient understanding

- Global attainment for your research

- Manuscript accessibility in different formats ( Pdf, E-pub, Full Text, Audio)

- Unceasing customer service

Track the below URL for one-step submission https://juniperpublishers.com/online-submission.php 